\title{
Eksistensi Fungsi Dewan Perwakilan Daerah (DPD) Dalam Sistem Ketatanegaraan Indonesia Menurut Undang-Undang Dasar Negara Republik Indonesia 1945
}

\author{
Mulyadi Golap \\ Fakultas Hukum Universitas Muhammadiyah Sorong \\ Dosen Hukum Tata Negara \\ E-mail: golapmulyadi@gmail.com
}

Diterima:14 Januari 2017. Disetujui:22 Februari 2017. Dipublikasikan:1 Maret 2017

\begin{abstract}
ABSTRAK
Penelitian ini bertujuan untuk menganalisis peraturan perundang-undangan yang mengatur tentang peranan DPD dalam sistem parlemen di Indonesia pada saat ini dalam perspektif sistem bikameral efektif dan untuk menganalisis konstruksi hukum yang ideal dalam mengatur peranan DPD dalam sistem parlemen di Indonesia dalam rangka revitalisasi pemberdayaan DPD dalam sistem kelembagaan negara. Jenis penelitian yang digunakan yuridis normatif dan tipe penelitian dengan pendekatan perundang-undangan (statuteapproach), pendekatan perbandingan (comparationapproach) dan pendekatan konseptual (conceptual approach). Hasil penelitian menunjukan bahwa Peraturan perundang-undangan yang ada baik di dalam UUD NRI Tahun 1945, UU No 22 Tahun 2003 dan UU No 27 Tahun 2009 yangmengatur tentang DPD, masih kurang dari dari harapan awal pembentukanDPD. Hal ini dikarenakan Pasal-pasal yang terkait membatasi kewenangan DPD di bidang fungsi legislasi, fungsi anggaran dan fungsi pengawasan, Terjadi ketimpangan kewenangan yang berat sebelah antara DPD dan DPR, Pasal-pasal yang membatasi kewenangan DPD membuat tidakadanya suatu "double check" dan "check and balances". Dengan adanya peraturan perundang-undangan baik di dalam UUD NRI Tahun 1945, UU Nomor 22 Tahun 2003 serta UU Nomor 27 Tahun 2009 yang mengatur tentang DPD, perlu adanya suatu konstruksi hukum dalam rangka revitalisasi peranan DPD dalam sistem parlemen di Indonesia.
\end{abstract}

Kata Kunci: Fungsi DPD, Sistem Ketatanegaraan, UUD 1945

\section{PENDAHULUAN}

Suatu negara yang menyatakan demokratis harus mempunyai suatu lembaga perwakilan atau lembaga legislatif dan saat ini sering disebut dengan istilah parlemen. Hal ini dikarenakan bahwa lembaga tersebut merupakan lembaga penyalur aspirasi rakyat. Selain itu bahwa lembaga tersebut mempunyai fungsi pengawasan terhadap lembaga lain terutama lembaga eksekutif. Dalam UUD NRI Tahun 1945 sebelum diamandemen lembaga legislatif mengenal adanya MPR (Majelis Permusyawaratan Rakyat) dan DPR (Dewan perwakilan Rakyat).
Dalam tatanan baru wajah parlemen di Indonesia kemudian memunculkan pertanyaan bagaimanakah peranan kedua lembaga legislatif tersebut ${ }^{1}$. Sejarah mencatat bahwa badan badan negara yang dibuat oleh UUD 1945 sebelum amandemen merupakan bentuk transformasi dari aparatur pemerintahan Hindia Belanda ${ }^{2}$.

DPR dalam UUD NRI Tahun 1945 sebelum amandemen merupakan tempat

\footnotetext{
${ }^{1}$ amandementelahmengalamiperubahansebanyak empat kali

${ }^{2}$ Harun Alrasyid, Naskah UUD 1945 sesudah diubah empat kali oleh MPR (Jakarta:UIPress)
} 
bagi para partai politik hasil pemilu, jadi tidak merefleksikan semua suara rakyat Indonesia. Oleh karena itu dibentuklah utusan golongan dan utusan daerah yang kemudian berkumpul di dalam suatu lembaga yang lebih besar yaitu MPR.

Pasca reformasi terjadi sebuah proses transisi yang sangat penting bagi struktur ketatanegaraan di Indonesia. Yaitu amandemen UUD NRI Tahun 1945 yang ingin merombak peraturan yang dianggap tidak sesuai dengan konsep negara demokrasi modern. Dan salah satu perubahan konstitusi yang sangat penting adalah lahirlah DPD dalam sistem parlemen di Indonesia. Sehingga Indonesia kemudian berubah menjadi bikameral, dari yang sebelumnya menganut konsep sistem unikameral.

Harapan dari DPD dalam konsep bikameralisme ialah diharapkan mampu menjaring semua aspirasi rakyat diseluruh Indonesia. Selain itu juga diharapkan DPD memperkuat peranan parlemen di Indonesia. Akan tetapi kemudian terjadi sebuah permasalahan ketika DPD tidak mempunyai peranan yang sama dengan DPR. Sehingga tidak mempunyai Powers of Legislations yang sama ketika dua kamar ini berkumpul untuk merumuskan UU.

Di dalam kajian peranan DPD di Indonesia, sebelumnya memang diulas sedikit dalam penjelasan sistem dua kamar (bikameral). Dalam perspektif tersebut disebutkan bagaimana ketika DPD di Indonesia dibandingkan dengan Negara-negara lain di dunia yang menganut sistem bikameral. Dalam ulasan tersebut dijelaskan bahwa sesungguhnya bagaimanakah peranan yang tidak lazim yang digunakan oleh konstitusi Indonesia dalam mengatur DPD dalam sistem parlemen yang dianut. Hal inilah yang kemudian membuat efektifitas pembuatan peraturan perundang-undangan menjadi kurang optimal.
Kurang maksimalnya peranan DPD tersebut terjadi ketika konstitusi masih bersifat "setengah-setengah" dalam mengatur peranan kamar kedua (DPD) dalam UUD NRI Tahun 1945. Disebutkan oleh Saldi Isra dan Zainal Abidin Mochtar ${ }^{3}$ dalam jurnal hukumnya berjudul Menuju Bikameral Efektif...yang mengklasifikasikan peraturan perundang-undangan dalam mengatur kewenangan serta analisis kelemahan DPD dalam sistem parlemen di Indonesia. Di dalam jurnal hukum tersebut dijelaskan secara rinci tentang peraturan-peraturan perundangundangan baik UUD NRI Tahun 1945 maupun UU No. 27 Tahun 2009 Tentang MPR, DPR, DPD, DPRD.

Dalam Pasal-pasal yang tertuang yang dalam peraturan perundang-undangan tersebut, terlihat bahwa peranan yang diberikan kepada DPD masih sangat lemah dalam sistem parlemen di Indonesia. Hal tersebut juga tidak terlepas dari perbandingan dengan negara lain di dunia yang menganut sistem yang sama seperti di Indonesia. Padahal sistem parlemen yang saat ini dibangun berorientasi kepada sistem bikameral yang pada dasarnya memberikan proporsionalitas yang seimbang antara masing-masing kamar. Sehingga akibat dari pemberdayaan yang kurang terhadap DPD mengakibatkan tidak optimalnya fungsi legislasi dalam proses pembuatan peraturan perundangundangan.

Walaupun wewenang yang dimiliki sangat terbatas, tentu DPD harus tetap menjalankan fungsinya sesuai dengan tujuan awal pembentukan yaitu memberikan saluran kepada daerah dalam proses pengambilan keputusan

\footnotetext{
${ }^{3}$ Saldi Isra, Zainal Arifin Mochtar, Мепијu Bikameral Efektif Dalam Rangka Memperkuat Fungsi Legislasi DPD, http:// www.bikameral.html, diakses pada tanggal 14 Agustus 2013.
} 
nasional yang terkait dengan kepentingan daerah. Sesuai dengan hakikat keberadaannya sebagai perwakilan daerah, tugas utama DPD adalah menyerap dan mengartikulasikan aspirasi daerah. Oleh karena itu harus terdapat hubungan yang jelas dan erat antara anggota DPD dengan daerah yang diwakili ${ }^{4}$.

Berikut adalah beberapa dampak yang ditimbulkan oleh adanya kelemahan peran DPD sebagai kamar kedua dalam sistem parlemen di Indonesia.

a. Kurang maksimal dalam pembuatan produk pembuatan peraturan perundang-undangan karena hanya menjadikan kamar pertama (DPR) sebagai tumpuan utama.

b. Produk perundang-undangan tidak menyerap aspirasi masyarakat secara utuh dikarenakan perbedaan yang tajam antara kewenangan DPR dan DPD dalam tugas dan fungsi legislasi.

c. Produk perundang-undangan banyak mengalami pergantian dalam waktu yang singkat akibat proses legislasi kurang matang. Padahal hal tersebut dapat dicegah dengan lebih memberdayakan peran DPD dalam proses legislasi.

Jadi dapat disimpulkan bahwa dalam rangka mewujudkan struktur parlemen di Indonesia yang lebih baik diperlukan suatu terobosan dalam sistem ketatanegaraan kita. Dinamika politik yang terus berkembang dalam proses demokratisasi mempengaruhi organorgan negara tidak hanya dalam wilayah eksekutif. Melainkan juga secara utuh,

\footnotetext{
4 Muchamad Ali Safa'at," DPD SEBAGAI LEMBAGA PERWAKILAN DAERAH DAN PROSES PENYERAPAN ASPIRASI" Disampaikan pada Focus Group Discussion "KonstruksiPeran Dewan Perwakilan Daerah RI Dalam Sistem Ketatanegaraan Indonesia (Revitalisasi PeranPenyerapan Aspirasi Masyarakat DPD RI)". Kerjasama PPK Fak. Hukum Unibraw dan DPD RI. Malang, 30 Juli 2009.
}

termasuk juga didalamnya legislatif dan juga yudikatif. Fungsi check and balances ketiga lembaga tersebut berjalan efektif ketika masing-masing lembaga memiliki struktur yang baik dan bisa memainkan tugas dan fungsi dengan optimal.

\section{METODE PENELITIAN}

Jenis penelitian yang digunakan yuridis normatif yang menekankan pada penelitian pustaka yang didukung. Analisis dilakukan terhadap peraturan perundang-undangan yang mengatur tentang undang-undang Nomor 22 Tahun 2003 serta undang-undang Nomor 27 Tahun 2009 yang mengatur tentang DPD.

Tipe penelitian yang digunakan adalah pendekatan perundang-undangan (statuteapproach) dengan menganalisa berbagai regulasi dan peraturan perundang-undangan, dan pendekatan perbandingan (comparationapproach) dan pendekatan konseptual (conceptual approach) yang dilakukan dengan berpangkal pada pandangan-pandangan dan doktrin terkait dengan isu hukum yang sedang diangkat.

\section{PEMBAHASAN}

\section{Peraturan Perundang-Undangan Yang Mengatur Tentang Peranan DPD Dalam Sistem parlemen di Indonesia Pada Saat ini Dalam Perspektif Sistem Bikameral Efektif.}

Dewan Perwakilan Daerah (DPD) memiliki dasar konstitusional dalam Pasal 22C dan Pasal 22D UUD 1945. Dalam Pasal 22C dan Pasal 22D UUD 1945 mengatur tentang eksistensi, kedudukan dan fungsi DPD. Pasal 22C menyebutkan bahwa:
(1) Anggota Dewan Perwakilan Daerah dipilih dari setiap provinsi melalui pemilihan umum. 
(2) Anggota Dewan Perwakilan Daerah dari setiap provinsi jumlahnya sama dan jumlah seluruh anggota Dewan Perwakilan Daerah itu tidak lebih dari sepertiga jumlah anggota Dewan Perwakilan Rakyat.

(3) Dewan Perwakilan Daerah bersidang sedikitnya sekali dalam setahun.

(4) Susunan dan kedudukan Dewan Perwakilan Daerah diatur dengan undang-undang.

Kemudian dalam Pasal 22D ditegaskan:

(1) Dewan Perwakilan Daerah dapat mengajukan kepada Dewan Perwakilan Rakyat rancangan undang-undang yang berkaitan dengan otonomi daerah, hubungan pusat dan daerah, pembentukan dan pemekaran serta penggabungan daerah, pengelolaa sumber daya alam dan sumber daya ekonomi lainnya, serta yang berkaitan dengan perimbangan keuangan pusat dan daerah.

(2) Dewan Perwakilan Daerah ikut membahas rancangan undangundangan yang berkaitan dengan otonomi daerah; hubungan pusat dan daerah; pembentukan, pemekaran, dan penggabungan daerah; pengelolaan sumber daya alam dan sumber daya ekonomi lainnya, serta perimbangan keuangan pusat dan daerah; serta memberikan pertimbangan kepada Dewan Perwakilan Rakyat atas rancangan undang-undang anggaran pendapatan dan belanja negara dan rancangan undangundang yang berkaitan dengan pajak, pendidikan, dan agama.

(3) Dewan Perwakilan Daerah dapat melakukan pengawasan atas pelaksanaan undang-undang mengenai; otonomi daerah, pembentukan, pemekaran dan penggabungan daerah, hubungan pusat dan daerah, pengelolaan sumber daya alam dan sumber daya ekonomi lainnya, pelaksanaan anggaran pendapatan dan belanja negara, pajak, pendidikan, dan agama serta menyampaikan hasil pengawasannya itu kepada Dewan Perwakilan Rakyat sebagai bahan pertimbangan untuk ditindaklanjuti.

(4) Anggota Dewan Perwakilan Daerah dapat diberhentikan dari jabatannya, yang syarat-syarat dan tata caranya diatur dalam undangundang.

Berdasarkan ketentuan di atas yang mengatur kedudukan dan fungsi DPD, memberikan perubahan terhadap sistem perwakilan dalam ketatanegaraan Indonesia yang sebelumnya tidak menampakkan bentuk perwakilan yang sebenarnya $^{5}$. Dengan kehadiran DPD tersebut, dalam sistem perwakilan Indonesia, DPR didukung dan diperkuat oleh DPD. DPR merupakan lembaga perwakilan berdasarkan aspirasi dan paham politik rakyat sebagai pemegang kedaulatan, sedangkan DPD merupakan

\footnotetext{
5 Sistem perwakilan dalam praktek ketatanegaraan yang berlaku di dunia, hanya dikenal dua kemungkinan struktur parlemen, yaitu sistem perwakilan satu kamar (unikameral) dan sistem perwakilan dua kamar (bikameral). Struktur ketatanegaraan sebagaimana diatur dalam Pasal 2 ayat (1), tidak mengenal sistem perwakilan bikameral, karena struktur kelembagaan MPR berdiri sendiri selain DPR dan DPD. Hal ini terjadi karena susunan MPR terdiri atas anggota DPR dan anggota DPD, sehingga memberikan kedudukan MPR sebagai lembaga yang terlepas sendiri yang tidak terdiri atas DPR dan DPD sebagai kelembagaan. Dengan struktur MPR seperti ini pun, Indonesia memberlakukan sistem perwakilan yang unik di dunia berupa sistem perwakilan trikameral. Lihat juga Jimly Asshaddiqie, Format Kelembagaan Negara dan Pergeseran Kekuasaan Dalam UUD 1945, FH UII Press, Cet. Kedua, Yogyakarta, 2005, hlm. 275-276.
} 
lembaga perwakilan penyalur keanekaragaman aspirasi daerah. Keberadaan lembaga DPD merupakan upaya menampung prinsip perwakilan daerah $^{6}$. Oleh Jimly Asshiddiqie, unsur anggota DPR didasarkan atas prosedur perwakilan politik (political representation), sedangkan anggota DPD yang merupakan cerminan dari prinsip regional representation dari tiaptiap daerah provinsi ${ }^{7}$.

Dalam pandangan MPR, pengaturan keberadaan DPD dalam struktur ketatanegaraan Indonesia menurut UUD 1945, antara lain dimaksudkan untuk:

1. memperkuat ikatan daerah-daerah dalam wadah Negara Kesatuan Republik Indonesia dan memperteguh persatuan kebangsaan seluruh daerah;

2. meningkatkan agregasi dan akomodasi aspirasi dan kepentingan daerah-daerah dalam perumusan kebijaksanaan nasional berkaitan dengan negara dan daerah;

3. mendorong percepatan demokrasi, pembangunan dan kemajuan daerah secara serasi dan seimbang.

Keberadaan daerah sebagaimana dimaksud dalam Pasal 18 ayat (1) dan otonomi daerah sebagaimana dimaksud dalam Pasal 18 ayat (5) berjalan sesuai dengan keberagaman daerah dalam rangka kemajuan bangsa dan negara ${ }^{8}$.

Pasal 22C ayat (4) UUD 1945 menyatakan bahwa: "Susunan dan kedudukan Dewan Perwakilan Daerah diatur dengan undang-undang”. Berdasarkan Pasal 22C ayat (4) inilah, maka Undang-Undang Nomor 22 Tahun 2003 sebagaimana telah diubah dengan Undang-Undang Nomor 27 Tahun 2009

\footnotetext{
6 Panduan Pemasyarakatan Undang-Undang Dasar Negara Republik Indonesia Sesuai dengan Urutan Bab, Pasal, dan Ayat, Sekretariat Jenderal MPR RI, 2005, hlm. 93.

7 Jimly Asshiddiqie, Format Kelembagaan Negara ..., Op.Cit., hlm. 38 dan 49.

8 Panduan Pemasyarakatan Undang-Undang Dasar ..., Op.Cit., hlm. 93
}

yang mengatur lebih jelas berkaitan dengan susunan dan kedudukan DPD.

Pasal 221 menegaskan bahwa "DPD terdiri atas wakil daerah provinsi yang dipilih melalui pemilihan umum". Kemudian dalam Pasal 222 menegaskan bahwa "DPD merupakan lembaga perwakilan daerah yang berkedudukan sebagai lembaga negara. Hal ini apabila dikaitkan dengan Pasal 67 dan Pasal 68 Undang-Undang Nomor 27 Tahun 2009, maka DPD dan DPR memiliki kedudukan yang sama sebagai lembaga negara, sedangkan tingkat keterwakilan yang berbeda sebagai lembaga perwakilan, dimana DPD merupakan lembaga perwakilan daerah, sedangkan DPR merupakan lembaga perwakilan rakyat.

Kedudukan DPD sebagai lembaga negara berkaitan dengan makna kedudukan dari suatu lembaga negara. Oleh Philipus M. Hadjon ${ }^{9}$, yang dimaksudkan dengan kedudukan lembaga negara, pertama kedudukan diartikan sebagai posisi suatu lembaga negara dibandingkan dengan lembaga negara lain, dan aspek kedua dari pengertian kedudukan lembaga negara adalah posisi suatu lembaga negara didasarkan pada fungsi utamanya. Untuk itu, analisis dalam penulisan ini menyangkut kedudukan DPD sebagai lembaga negara, yang dikaitkan dengan pengertian lembaga negara baik dari aspek posisi DPD yang dibandingkan dengan lembaga negara lainnya, terutama MPR. Selain itu pula, kedudukan DPD yang berkaitan dengan fungsi utama dari DPD.

Untuk memahami konsep lembaga negara apabila menggunakan pendekatan perbandingan konsep lembaga negara di

\footnotetext{
${ }^{9}$ Philipus M. Hadjon, Lembaga Tertinggi dan Lembaga-Lembaga Tinggi Negara Menurut Undang-Undang Dasar 1945 Suatu Analisa Hukum dan Kenegaraan, PT Bina Ilmu, Surabaya, 1992, hlm. X.
} 
Jerman, Konstitusi Jerman membedakan antara state organ dan constitutional organ. Constitutional organ hanyalah menyangkut lembaga-lembaga (organ) yang status dan kewenangannya langsung diatur oleh konstitusi. Sedangkan state organs adalah lembagalembaga dalam negara Jerman yang dianggap bertindak atas nama negara Jerman. Dengan perbandingan sistem ketatanegaraan Jerman, hendaklah kita bedakan lembaga-lembaga negara yang status dan kewenangannya langsung diatur oleh UUD dengan lembaga negara yang hanya disebut dalam UUD namun kewenangannya didelegasikan pengaturannya oleh undang-undang ${ }^{10}$.

Menurut Jimly Asshidiqie ${ }^{11}$, lembaga negara dapat diartikan dalam beberapa pengertian. Pertama, organ negara paling luas mencakup setiap individu yang menjalankan fungsi law-creating dan law-applying; Kedua, organ negara dalam arti luas tetapi lebih sempit dari pengertian pertama, yaitu mencakup individu yang menjalankan fungsi lawcreating atau law-applying dan juga mempunyai posisi sebagai atau dalam struktur jabatan kenegaraan atau jabatan pemerintahan; Ketiga, organ negara dalam arti yang lebih sempit, yaitu badan atau organisasi yang menjalankan fungsi law-creating dan/atau law-applying dalam kerangka struktur dan sistem kenegaraan atau pemerintahan; Keempat, organ atau lembaga negara itu hanya terbatas pada pengertian lembagalembaga negara yang dibentuk

\footnotetext{
${ }^{10}$ Philipus M. Hadjon, "Eksistensi, Kedudukan, dan Fungsi MPR Sebagai Lembaga Negara Dalam Sistem Ketatanegaraan Republik Indonesia", Makalah Seminar Peran MPR-RI Pasca Amandemen UUD 1945, yang dilaksanakan oleh Sekretariat Jenderal MPR-RI bekerjasama dengan Fakultas Hukum Universitas Airlangga, di Surabaya, 22 Desember 2005, hlm. 3-4.

11 Jimly Asshidiqie, Perkembangan dan Konsolidasi Lembaga Negara Pasca Reformasi, Konstitusi Press, Jakarta, 2006, hlm.40-42.
}

berdasarkan UUD, UU, atau oleh peraturan yang lebih rendah; dan Kelima, untuk memberikan kekhususan kepada lembaga-lembaga negara yang berada di pusat yang pembentukannya ditentukan dan diatur oleh UUD 1945, atau disebut sebagai lembaga tinggi negara. Dengan menggunakan konsepkonsep di atas, maka DPD dalam kedudukannya merupakan lembaga negara yang dikategorikan sebagai constitutionalorgan, karena pengaturan dan kewenangannya langsung diatur oleh UUD 1945.

Untuk memahami kedudukan DPD sebagai lembaga perwakilan yang bersifat bikameral atau tidak, maka dapat dilihat dari hubungan konstitusional kedudukan DPD dengan MPR termasuk di dalamnya pula hubungan antara DPD dengan DPR. Hubungan konstitusional antara kedudukan DPD dengan MPR dapat dilihat dalam Pasal 2 ayat (1), Pasal 3 dan Pasal 8 ayat (2) dan ayat (3) UUD 1945. Hubungan antara DPD dan MPR berdasarkan Pasal 2 ayat (1) merupakan hubungan struktural dimana pengaturannya berkaitan dengan kedudukan anggota DPD sebagai anggota MPR. Pengaturan ini memiliki makna konstitusional bahwa DPD memiliki peran yang sama dengan DPR dalam melaksanakan wewenang MPR. Berdasarkan Pasal 3 dan Pasal 8 ayat (2) dan ayat (3), serta Pasal 37 nampak adanya sinkronisasi antara DPD dan DPR dalam menjalankan wewenang MPR.

Beberapa pasal dalam UUD 1945 yang pengaturannya tidak konsisten dan hubungan yang tidak sinkron dengan kedudukan anggota DPD sebagai anggota MPR sebagaimana diatur dalam Pasal 2 ayat (1) di antaranya, Pasal 7A, Pasal 7B, Pasal 9 ayat (1) dan ayat (2). Dalam Pasal 7A, diatur bahwa Presiden dan Wakil Presiden dapat diberhentikan dalam masa jabatannya oleh MPR atas usul DPR serta dalam Pasal 7B yang 
mengatur prosedur usul pemberhentian Presiden dan Wakil oleh DPR melalui MPR dan Mahkamah Konstitusi. Sedangkan dalam Pasal 9 ayat (1) dan ayat (2) mengatur sumpah jabatan Presiden dan Wakil Presiden dihadapan MPR atau DPR.

Berdasarkan

pengaturan

konstitusional yang berkaitan kedudukan DPD menurut UUD 1945, dimana tidak adanya sinkronisasi antara pengaturan pasal-pasal dalam UUD 1945, nampak bahwa DPD yang merupakan lembaga perwakilan daerah yang berkedudukan sebagai lembaga negara tidak sesuai dengan gagasan pembentukan DPD dan sistem perwakilan bikameral. Gagasan pembentukan DPD pada hakikatnya untuk memperkuat integrasi bangsa. Alasan keberadaan DPD yang dimaksudkan untuk meningkatkan agregasi dan akomodasi aspirasi dalam konteks perumusan kebijakan nasional bagi kepentingan negara dan daerahdaerah sekaligus merupakan sebuah upaya untuk meningkatkan pemberdayaan daerah dan masyarakat yang ada di seluruh wilayah Indonesia.

Gagasan pembentukan DPD pun merupakan bagian dari reformasi struktur parlemen Indonesia. Oleh Jimly Asshiddiqie $^{12}$, semula, reformasi struktur parlemen Indonesia yang disarankan oleh banyak kalangan ahli hukum dan politik supaya dikembangkan menurut sistem bikameral yang kuat (strong bicameralism) dalam arti kedua kamar dilengkapi dengan kewenangan yang sama kuat dan saling mengimbangi satu sama lain. Untuk itu masing-masing kamar diusulkan, dilengkapi dengan hak veto. Usulan semacam ini berkaitan erat dengan sifat kebijakan otonomi daerah yang cenderung luas dan hampir mendekati pengertian sistem federal.

12 Jimly Asshiddiqie, Konstitusi dan Konstitusionalisme Indonesia, Konstitusi Press, Jakarta, 2005, hlm. 186-187.
Namun demikian, Perubahan Ketiga UUD 1945 hasil Sidang Tahunan Majelis Permusyawaratan Rakyat Tahun 2001 justru mengadopsi gagasan parlemen bicameral yang bersifat soft. Kedua kamar dewan perwakilan tersebut tidak dilengkapi dengan kewenangan yang sama kuat. Yang lebih kuat tetap DPR, sedangkan kewenangan DPD hanya bersifat tambahan dan terbatas pada hal-hal yang berkaitan langsung dengan kepentingan daerah.

Kedudukan DPD sebagaimana telah dikemukakan diatas, pada hakikatnya tidak sesuai dengan gagasan pembentukan DPD dalam proses reformasi struktur parlemen Indonesia. DPD sebagai lembaga negara tidak memiliki zelfstandigheid atau wewenang mandiri berkaitan dengan pengambilan keputusan hukum dalam menjalankan fungsi legislasi. Berdasarkan Pasal 2 ayat (1) UUD 1945, dengan adanya lembaga baru DPD dalam struktur MPR, maka pengaturan tersebut menganut sistem perwakilan dua kamar (bicameral system). Tetapi pengaturan dalam Pasal 2 ayat (1) ini tidak memberikan ketegasan terhadap pemberlakuan sistem perwakilan dua kamar, dimana MPR terdiri dari anggota DPR dan anggota DPD.

Berbicara mengenai kedudukan DPD sebagai lembaga perwakilan, hal ini tidak mungkin dilepaskan dari konsepsi demokrasi. Dalam konsepsi demokrasi terkandung asas dasar, yakni kedaulatan rakyat menentukan jalannya pemerintahan. Perwujudan asas ini dalam kehidupan pemerintahan seharihari tergambar dari keikutsertaan rakyat memutuskan kebijakan-kebijakan pemerintahan. DPD selaku lembaga perwakilan daerah yang memiliki karakter keterwakilan berdasarkan daerah-daerah pada hakikatnya memiliki karakter keterwakilan yang lebih luas dari DPR, karena dimensi keterwakilannya berdasarkan seluruh 
rakyat yang terdapat pada daerah-daerah tersebut. Untuk itu, pengaturan kedudukan DPD yang merupakan lembaga perwakilan daerah dan berkedudukan sebagai lembaga negara, sebagai perwujudan Pasal 1 ayat (2) UUD 1945, hendaknya merupakan dasar perumusan kedudukan DPD.

\section{Konstruksi Hukum Yang Ideal Dalam Mengatur Peranan DPD Dalam Sistem Parlemen di Indonesia Dalam Rangka Revitalisasi Pemberdayaan DPD Dalam Sistem kelembagaan Negara}

Sejarah politik dan kekuasaan di negara ini pada dasarnya berbasis pada kepentingan daerah (lokal). Hal ini ditandai dengan keberadaan dan sejarah kerajaan-kerajaan di banyak daerah di Indonesia, yang masing-masing memiliki otonomi bahkan kedaulatan sendiri-sendiri. Di masa sebelum kemerdekaan, eksistensi kekuasaan lokal yang independen satu sama lain itu sebagiannya telah menjadi kaki tangan kolonialisme, termasuk di dalamnya diperhadapkan satu sama lain dengan strategi devide et impera (politik pecah belah). Dalam kondisi seperti itulah, kalangan penjajah dengan begitu leluasa melakukan eksploitasi sumber daya manusia, sumber daya alam dan sumber daya lainnya dari bumi nusantara, dimana hasilnya diekstrasi ke luar untuk membangun negeri mereka, yang membuat mereka sekarang menjadi negara maju.

Para pendiri negara (founding fathers) sangat menyadari bahwa olah kuasa dan politik (power and political exercise) dalam bernegara harus selalu didasarkan pada prinsip dan eksistensi kebhinekaan berbasis daerah. Arah kebijakan negara haruslah ditetapkan berdasarkan prinsipprinsip kedaulatan dan permusyawaratan dari elemen-elemen bangsa itu, yang dalam terminologi generiknya dikenal dengan kata-kata demokrasi dan musyawarah. Karena disepakati sebagai negara yang berbentuk republik, maka yang berperan dalam proses-proses penentuan arah kehidupan berbangsa itu adalah para wakil dari elemen-elemen bangsa yang juga mewakili unsur-unsur daerah. Para anggota Badan Penyelidik Usaha Persiapan Kemerdekaan Indonesia (BPUPKI) dalam menyusun konstitusi mempersiapkan kemerdekaan Indonesia di tahun 1945 secara jelas menyadari kebhinekaan itu. Prof. Muhammad Yamin, dalam sidang BPUPKI menyatakan bahwa "permusyawaratanrakyat adalah wujud tertinggi kedaulatan rakyat, dan kedaulatan rakyat syaratnyaadalah adanya wakil langsung rakyat dan daerah".

Pemikiran Prof. Muhammad Yamin yang menggambarkan ruh konstitusi kita sangat sesuai dengan kondisi kebangsaan Indonesia dan kaidah-kaidah kehidupan masyarakat negara modern. Bangunan lembaga pemegang kedaulatan rakyat merupakan perpaduan antara wakilrakyat dan wakildaerah yang dipilih langsung oleh rakyat. Dalam sejarah politik Indonesia era kemerdekaan, perwujudan pemikiran itu telah berkembang dinamis dari periode ke periode, dan pada tahun 1998, dengan gerakan reformasi secara prinsip menemukan bentuknya yang mendasar dalam perubahan makna dan paradigma. Amandemen konstitusi yang sudah dilakukan sebanyak empat kali di mana tampaknya akan terus berproses dalam rangka penyempurnaan telah melahirkan sistem perwakilan dalam dua lembaga, yakni lembaga yang mewakili rakyat dan lembaga yang mewakili wilayah. Dalam konstitusi kita hasil amandemen bangunan kelembagaan yang berdaulat itu sangat jelas, yakni yang mewakili rakyat melalui partaipartai politik adalah lembaga Dewan Perwakilan Rakyat (DPR) dan Dewan Perwakilan Rakyat Daerah (DPRD) yang mewakili rakyat melalui entitas daerah 
atau wilayah adalah lembaga Dewan Perwakilan Daerah (DPD), yang anggota-anggotanya dipilih melalui jalur perseorangan.

Penataan kelembagaan negara melalui amandemen konstitusi ketiga yang kemudian melahirkan DPD tidak serta merta muncul jatuh dari langit. Karena kecuali ia merupakan pengejawantahan dari ruh yang menjiwai lahirnya UUD 1945 seperti yang sedikit digambarkan diatas, juga merupakan produk sosiologi politik setelah melalui proses pergumulan panjang dalam sejarah hubungan pusat dan daerah di negeri ini, sebagai bagian dari tuntutan reformasi 1998. Sejumlah kondisi itu antara lain:

Pertama, Penyelenggaraan negara yang sentralistik yang berlangsung sejak era Orde Lama hingga Orde Baru telah secara signifikan menimbulkan akumulasi kekecewaan daerah terhadap pemerintah pusat, yang sekaligus merupakan indikasi kuat kegagalan pemerintahan pusat dalam mengelola daerah sebagai basis berdirinya bangsa ini. Maka, di awal reformasi semangat itu kemudian diwujudkan dalam sistem desentralisasi dan otonomi daerah, yaitu suatu pilihan politik dalam pengelolaan NKRI dimana daerah harus menjadi aktor sentral dalam pengelolaan republik ini. Keluarnya Undang-Undang Nomor 22 tahun 1999 tentang Pemerintahan Daerah merupakan realisasi dari kebijakan desentralisasi itu, yang kemudian diperkuat dalam Perubahan Kedua UUD 1945 seperti tertuang pada BAB VI Pemerintahan Daerah Pasal 18, 18A, dan 18B.

Kedua, di masa Orde Baru dan di awal era reformasi (bahkan hingga sekarang) persepsi publik terhadap eksistensi dan perilaku partai politik (parpol) kurang sejalan dengan harapan publik, karena sistem kepartaian kita masih sangat sentralistik. Sistem seperti itu sudahlah pasti selalu menyulitkan perjuangan kepentingan daerah dalam proses-proses pengambilan kebijakan ditataran nasional, akibat dari kebijakan yang sentralistik yang secara alamiah berseberangan dengan aspirasi desentralistik.

Ketiga, kehadiran DPD merupakan produk dari refleksi kritis terhadap eksistensi utusan daerah dan utusan golongan yang mengisi formasi Majelis Permusyawaratan Rakyat (MPR) dalam sistem keterwakilan kita di era sebelum reformasi. Mekanisme pengangkatan dari utusan daerah dan utusan golongan bukan saja merefleksikan sebuah sistem yang tidak demokratis; melainkan juga mengaburkan sistem perwakilan yang seharusnya dibangun dalam tatanan kehidupan negara modern yang demokratis. Maka DPD lahir sebagai bagian dari upaya untuk memastikan bahwa wilayah atau daerah harus memiliki wakil untuk memperjuangkan kepentingannya secara utuh di tatarnasional, yang sekaligus berfungsi menjaga keutuhan NKRI.

Keempat, kehadiran DPD mengandung makna bahwa sekarang ada lembaga yang mewakili kepentingan lintas golongan atau komunitas yang sarat dengan pemahaman akan budaya dan karakteristik daerah. Para wakil daerah bukanlah wakil dari suatu komunitas atau sekat komunitas di daerah (antara lain yang berbasis ideologi atau parpol), melainkan figurfigur yang bisa mewakili seluruh elemen yang ada di daerah. Dengan sendirinya, para wakil daerah baru bisa dikatakan "sungguh-sungguh berada di atas kepentingan golongan" apabila yang bersangkutan benar-benar memahami apa yang menjadi muatan daerah yang diwakilinya (komunitas berikut budaya dan ruhnya, geografisnya, kandungan buminya, dan sebagainya), dan sekaligus harus terbebas dari semua sekat ideologis. Kita semua tahu dan menyadari, apalagi di era kebebasan berorganisasi dan berekspresi yang 
dijamin oleh konstitusi kita, bahwa parpol yang eksis di daerah umumnya merepresentasikan kepentingan menurut kebijakan parpol pada tingkat pusat atau dengan kata lain parpol masih berwatak sentralistik. Tepatnya, kalau seorang wakil daerah merupakan bagian dari komunitas yang primary group-nya berbasis parpol, maka sangat berpotensi (untuk tidak dikatakan pasti) mengabaikan kepentingan daerah yang diwakilinya apabila itu tidak sejalan dengan kepentingan partainya.

\section{PENUTUP}

\section{Kesimpulan}

Bahwa peraturan perundang-undangan yang ada baik di dalam UUD NRI Tahun 1945, UU No 22 Tahun 2003 dan UU No 27 Tahun 2009 yang mengatur tentang DPD, masih kurang dari dari harapan awal pembentukan DPD. Hal ini dikarenakan antara lain: a. Pasal-pasal yang terkait membatasi kewenangan DPD di bidang fungsi legislasi, fungsi anggaran dan fungsi pengawasan; $b$. Terjadi ketimpangan kewenangan yang berat sebelah antara DPD dan DPR, dan kewenangan yang jauh dominan membuat DPD hanya bertindak sebagai auxiliary atau penunjang terhadap fungsi DPR sehingga DPD disebut juga sebagai co-legislator daripada legislator yang sesungguhnya; c. Pasal-pasal yang membatasi kewenangan DPD di bidang fungsi legislasi, fungsi pengawasan dan fungsi anggaran membuat tidak adanya suatu "double check" dan "check and balances" dalam suatu lembaga pembuat peraturan perundang-undangan di Indonesia. Dengan adanya peraturan perundang-undangan baik di dalam UUD NRI Tahun 1945, UU No 22 Tahun 2003 serta UU No 27 Tahun 2009 yang mengatur tentang DPD, perlu adanya suatu konstruksi hukum dalam rangka revitalisasi peranan DPD dalam sistem parlemen di Indonesia. Adapun langkah-langkah yang bisa ditempuh adalah dengan melakukan amandemen terhadap UUD NRI Tahun 1945. Amandemen tersebut dilakukan dengan menggunakan mekanisme yang sesuai dengan pasal 37 UUD NRI Tahun 1945 yang mengatur tentang mekanisme perubahan terhadap UUD NRI Tahun 1945. Revitalisasi yang dapat dilakukan adalah dengan mengacu pada prinsipprinsip sebagai berikut: a. DPD harus mempunyai kewenangan yang berimbang dengan DPD; b. DPD dan DPR mempunyai fungsi legislasi, fungsi anggaran dan fungsi pengawasan yang sama-sama efektif; c. Setiap anggota DPR dan DPD berhak untuk mengajukan rancangan undang-undang; d. Setiap rancangan undang-undang harus melalui kedua kamar tersebut sebelum menjadi sebuah produk undang-undang;

\section{DAFTAR PUSTAKA}

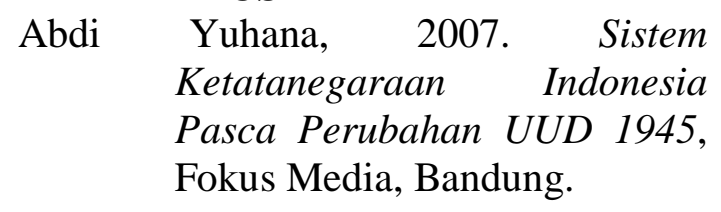

Abdul Latif, dkk, 2007. Buku Ajar Ilmu Negara. Program HibahKompetisi (PHK) A-2, Makassar.

Abdul Mukhtie Fadjar, 2002. Pengantar dalam Bambang Widjoyanto dkk (editor), Konstitusi Baru Melalui Komisi Konstitusi Independen, Pustaka Sinar Harapan, Jakarta.

Abu Daud Busroh, 2001. Ilmu Negara. Bumi Aksara, Jakarta.

Adnan Buyung Nasution, 1995. Aspirasi Pemerintahan Konstitusional di Indonesia Studi Socio-Legal atas Konstituante 1956-1959, Pustaka Utama Grafiti, Jakarta. 
Anton M. Moeliono, 1988. Kamus Besar Bahasa Indonesia, Departemen Pendidikan Kebudayaan RI, Jakarta.

Aulia Rachman, 2007. Sistem Pemerintahan Presidentil Sebelum dan Sesudah Perubahan UUD 1945: Studi Ilmiah Tentang Tipe Rezim, Tipe Institusi, danTipe Konstitusi, Disertasi, Program Doktor Pascasarjana Fakultas Hukum Universitas Indonesia, Jakarta.

Bagir Manan, 2003. DPR, DPD, dan MPR dalam UUD 1945 Baru, Fakultas Hukum Universitas Islam Indonesia (FH UII) Press, Yogyakarta.

Bivitri Susanti dkk, 2000.Semua Harus Terwakili: Studi Mengenai Reposisi MPR, DPR, dan Lembaga Kepresidenan Indonesia, Pusat Studi Hukum dan Kebijakan, Jakarta.

Bivitri Susanti, Penguatan Kewenangan DPD dan Pasal-pasal Lain yang Terkait di Bidang Legislasi, Anggaran, dan Pengawasan, Makalah disampaikan dalam Pertemuan AhliHukum Tata Negara, diselenggarakan oleh Univ. 45, Makassar

C.S.T. Kansil, 1984. Hukum Tata Negara Republik Indonesia. Bina Aksara, Jakarta.

Dahlan Thaib, 2002. Menuju Parlemen Bikameral: Studi

Konstitusional Perubahan Ketiga UUD 1945, Pidato Pengukuhan Guru Besar,
Fakultas Hukum UII, Yogyakarta.

Dahlan Thaib, dkk, 2004. Teori dan Hukum Konstitusi, Raja Grafindo Persada, Jakarta.

Deny Indrayana, 2007. Mendesain Presidensial yang Efektif, Bukan "Presiden Sial" atawa "Presiden Sialan", Makalah disampaikan dalam Pertemuan Ahli Hukum Tata Negara "Melanjutkan Perubahan UUD 1945 Negara RI”, Bukit tinggi.

Douglas V. Verney, 1992. Parliamentary Government and Presidential Government, dalam Parliamentary Versus Presidential Government, ArendLijphart (edit), Oxford Univerrsity Press.

Ellydar Chaidir, 2001. Hubungan Tata Kerja Presiden dan Wakil Presiden, Perspektif Konstitusi. UII Press, Yogyakarta.

Firmansyah Arifin, dkk, 2005. Lembaga Negara dan Sengketa Kewenangan Antarlembaga Negara. KRHN, Jakarta.

Frans Magnis Suseno, 1997. Etika Politik, Prinsip-Prinsip Moral Dasar Kenegaraan Modern: Gramedia Pustaka Utama, Jakarta.

Giovanni Sartori, 1997, Comprative Constitutional Engineering: An Inquiry into Structures, Incentives, and Outcomes. New York University Press.

$\begin{array}{cr}\text { HamdanZoelva, 2007. Artikel } \\ \text { Paradigma } & \text { Baru } \\ \text { Ketatangeraan } & \text { Pasca }\end{array}$


Perubahan UUD 1945,

Sekretariat Negara RI, Jakarta.

Hans Kelsen, 1995. Teori Hukum Murni:

Dasar-dasar Ilmu Hukum Empirik-Deskriptif (terj. Somardi), Rimdi Press, Jakarta.

1971. General Theory of Law and State, Russel \& Russel, New York.

Harun Alrasyid, 2002. Kajian Sistem Pemerintahan dan Ruang Lingkupnya, dalam Basement, Majalah Mahasiswa Universitas Pasundan, vol. 3., No. III, Juni, Bandung.

Presiden dan Pergantian
Presiden Dalam Hukum Positif
Indonesia, YLBHI, Jakarta.

HAS Natabaya, 2004. Lembaga (Tinggi) Negara Menurut UUD 1945, dalam Refly Harun dkk (editor), Menjaga Denyut Konstitusi: Refleksi Satu Tahun $M K$, Konstitusi Press, Jakarta.

Hendarmin Ranadireksa, 2007. Arsitektur Konstitusi Demokratik, Fokus Media, Bandung.

Irfan Fachruddin, 2004. Pengawasan Peradilan Administrasi Terhadap Tindakan Pemerintah. Alumni, Bandung.

Ismail Sunny, 1978. Pembagian Kekuasaan Negara. Penerbit Aksara Baru, Jakarta.

Jimly Asshidiqie \& Bagir Manan, 2006.

Gagasan Amademen UUD 1945 dan Pemilihan Presiden Secara Langsung: Sebuah
Dokumen Historis. Sekretariat jenderal \& Kepaniteraan Mahkamah Konstitusi RI, Jakarta.

Jimly Asshidiqie \& Ali Safa'at, 2006. Teori Hans Kelsen Tentang Hukum. Konstitusi Press, Jakarta.

Jimly Asshidiqie, 1996. Pergumulan Peran Pemerintah dan Parlemen Dalam Sejarah: Telaah Perbandingan Konstitusi Berbagai Negara, UI Press, Jakarta.

$\longrightarrow$ 2002. Konsolidasi Naskah UUD 1945 Setelah Perubahan Keempat. Pusat Studi Hukum Tata Negara Fakultas Hukum Universitas Indonesia, Jakarta.

Medan 2002. Presidensialis
dalam Gerak Politik yang
Tertawan: Menggagas Ulang
Prinsip-prinsip Lembaga
Kepresidenan, The Center for
Presidential and Parliamentary
Studies (CPPS) dan
Partenership for Governance
Reform in Indonesia, Jakarta.
$\longrightarrow$, 2004, 2005. Format Kelembagaan Negara dan Pergeseran Kekuasaan Dalam UUD 1945.Fakultas Hukum UII Press, Yogyakarta.

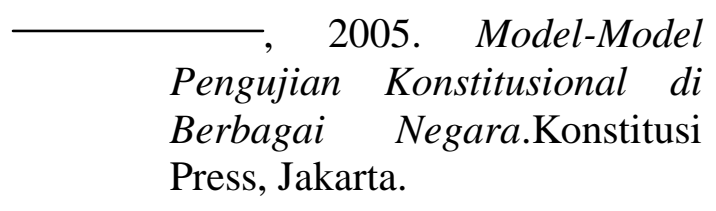
Press, Jakarta.

, 2006. Pengantar Ilmu Hukum Tata Negara. Jilid I, Sekretariat Jenderal Mahkamah 
Konstitusi Republik Indonesia, Jakarta.

, 2006. Pengantar Ilmu Hukum Tata Negara. Jilid II, Sekretariat Jenderal Mahkamah Konstitusi Republik Indonesia, Jakarta.

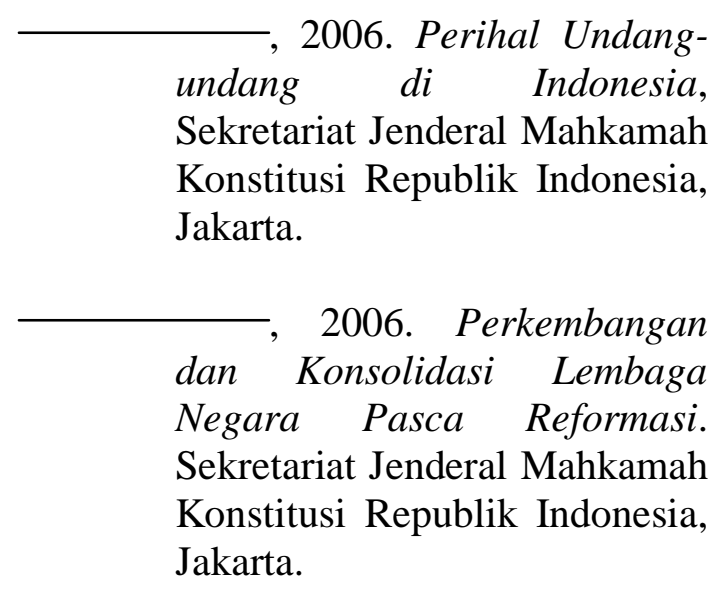

$\longrightarrow$, 2007. Pokok-Pokok Hukum Tata Negara Indonesia Pasca Reformasi. Buana Ilmu Populer, Jakarta.

Lembaga 2008. Hubungan Antar
Perubahan UUD 1945, Bahan
ceramah pada Diklatpim
Tingkat I Angkatan XVII
Lembaga Administrasi Negara,
Jakarta.

$\longrightarrow$, 2010. Konstitusi dan Konstitusionalisme Indonesia. Sinar Grafika, Jakarta.

John M. Echols dan Hassan Shadily, 1997.Kamus Inggris-Indonesia, Cetakan ke-XXIV, Gramedia PustakaUtama, Jakarta.

Laica M Marzuki. 2006. Berjalan-jalan di Ranah Hukum: Pikiranpikiran Lepas Prof. Dr. H.M. Laica Marzuki, S.H. Buku I. Sekretariat Jenderal dan
Kepaniteraan Mahkamah Konstitusi RI, Jakarta.

La Ode Husen. 2009. Negara Hukum, Demokrasi dan Pemisahan kekuasaan. PT Umitoha Ukhuwah Grafika. Makassar.

Made Pasek Diantha, 1990. Tiga-Tipe Pokok Sistem Pemerintahan Dalam Demokrasi Modern, Abardian, Bandung.

Marwan Mas, 2004. Pengantar Ilmu Hukum, Ghalia Indonesia, Jakarta.

M. Fajrul Falaakh, 2002. Metamorfosis MPR (Teka-teki Parlemen Berkamar Tiga), dalam harian Kompas, 19 April, Jakarta.

M. SollyLubis, 1982. Asas-asas Hukum Tata Negara. Alumni, Bandung.

Miriam Budiardjo, 2002. Dasar-dasar Ilmu Politik. PT Gramedia Pustaka Utama, Jakarta.

Moh. Mahfud MD, 1993. Dasar dan Struktur Ketatanegaraan Indonesia, UII Press, Yogyakarta.

Moh. Kusnardi dan Bintan R. Saragih, 1994. Susunan pembagian kekuasaan Menurut Sistem Undang-Undang Dasar 1945. PT Gramedia, Jakarta.

Montesquieu, 1993. Membatasi Kekuasaan-Telaah Mengenai Jiwa Undang-Undang (terj. J.R. Sunaryo), PT Gramedia Pustaka Utama, Jakarta.

Muhammad Alim, 2005. Teori Pembagian Kekuasaan Dalam Negara. Yogyakarta. 
Moh. Kusnardi dan Ibrahim Harmaily. 1988. Pengantar Hukum Tata Negara Indonesia. Cet. ke7.Pusat Studi Hukum Tata Negara Fakultas Hukum Universitas Indonesia, Jakarta.

Ni'matul Huda, 2003. Politik Ketatanegaraan Indonesiakajian Terhadap Dinamika Perubahan UUD 1945, FH UII PRESS, Yogyakarta.

\begin{tabular}{lrr}
\multicolumn{3}{r}{,2007. Lembaga Negara } \\
\hline dalam Masa & Transisi \\
Demokrasi. & UII & Press, \\
Yogyakarta. & &
\end{tabular}

Nurul Qamar, 2012. Pengantar Politik Hukum Ketatanegaraan. Pustaka Refleksi, Makassar.

Philipus M. Hadjon \& Tatiek Sri Djamiati, 2005. Argumentasi Hukum (Legal Argumentation/ Legal Reasoning). Gadjah Mada University Press, Yogjakarta.

R.M. Ananda B. Kusuma, 2004. Sistem Pemerintahan Indonesia, dalam Jurnal Konstitusi, Vol. 1 No. 1.,Mahkamah Konstitusi RI, Jakarta.

Romi Librayanto, 2008. Trias Politica Dalam Struktur Ketatanegaraan Indonesia. PuKAP, Makassar.

Saldi Isra, 2010. Pergeseran Fungsi Legislasi, Menguatnya Model Legislasi Parlementer Dalam Sistem Presidensial Indonesia. PT Raja Grafindo Persada, Jakarta.
Saldi Isra \& Zainal Arifin Mochtar, 2007. Konsep Ideal Bikameral yang Sesuai dengan Keadaan dan Pemerintahan Demokratis di Indonesia, Laporan Kajian, Parliamentary Reform Iniatiatives and DPD Empowerment (PRIDE) Sekretariat Jenderal DPD bekerjasama dengan UNDP, Jakarta.

Samidjo, 1986. Ilmu Negara. CV Armico, Bandung.

Sobirin Malian, 2001. Gagasan perlunya konstitusi baru pengganti UUD 1945, UII Press, Yogyakarta.

Soerjono Soekanto, 2003. Pokok-pokok Sosiologi Hukum, Raja Grafindo Persada, Jakarta.

Soimin dan Sulardi, 2004. Hubungan Badan Legislatif dan Yudikatif. UMM PRESS, Malang.

Sri Soemantri Martosoewignjo, 1981. Pengantar Perbandingan Antar Hukum Tata Negara, CV. Rajawali, Jakarta.

Sukarna, 1981. Sistem Politik. Alumni, Bandung.

Sumali, 2002. Reduksi Kekuasaan Eksekutif di Bidang Peraturan Pengganti Undang-undang (PERPU).UMM Press, Malang.

Sudargo Gautama, 1983. Pengertian Negara Hukum, Alumni, Bandung.

Suwoto Mulyosudarmo, 1997. Peralihan Kekuasaan (Kajian Teoritis dan Yuridis terhadap Pidato Nawaksara). PT Gramedia PustakaUtama, Jakarta. 
2004.

Pembaruan Ketatanegaraan Melalui Perubahan Konstitusi, Intrans dan Asosiasi Pengajar HTN dan HAN Jawa Timur, Surabaya.

Syachran Basah, 1992. Ilmu Negara. Pengantar, Metode dan Sejarah Perkembangan. Alumni, Bandung.

T.A. Legowo, 2002. Paradigma Check and Balances dalam Hubungan Eksekutif-Legislatif, dalam Laporan Hasil Konferensi Melanjutkan Dialog menuju Reformasi Konstitusi di Indonesia, International IDEA, Jakarta.

Usep Ranawijaya, 1983. Hukum Tata Negara Indonesia: Dasardasarnya, Ghalia Indonesia, Jakarta. 